\title{
Analysis of patterns of the open-pit mine water influx formation in the conditions of the Inhulets iron ore deposit using a three-dimensional geofiltration model
}

\author{
Vasyl Tymoshchuk ${ }^{1 *}$, Yevheniia Sherstiuk $^{1}$, and Tamara Morozova ${ }^{2}$ \\ ${ }^{1}$ National Mining University, Department of Hydrogeology and Engineering Geology, \\ 19 Yavornytskoho Ave., 49005 Dnipro, Ukraine \\ ${ }^{2}$ National Mining University, Department of Physics, 19 Yavornytskoho Ave., 49005 Dnipro, Ukraine
}

\begin{abstract}
The purpose is to study the patterns of groundwater influxe formation within the north-eastern side of the Private Joint-Stock Company "Inhuletskyi hirnycho-zbahachuvalnyi kombinat" (PJSC INHZK) open-pit mine in the conditions of disturbed hydrodynamic regime of the eastern adjacent side of the open-pit mine by the developed three-dimensional geofiltration model. The patterns have been determined of the open-pit mine water influx formation on the basis of a complex analysis of the actual data related to geological and hydrogeological structure of the iron ore deposit, the intensity and character of groundwater influx within the eastern side of the open-pit mine, and the results of numerical simulation of geofiltrational processes. By the results of inverse problems solutions, the geofiltration model reflects adequately the geological, hydrogeological, and geotechnical conditions of the studied territory where the technogenically disturbed hydrodynamic regime have been formed; the calculated values of the open-pit mine water influx within the eastern side of the open-pit mine and its north-eastern site, have been determined. It has been found that the values of groundwater influx and their distribution within the eastern side of the open-pit mine and its north-eastern site depend on the manner of the water-permeable alluvial strata occurrence on the eroded surface of seat clays, and the existence of a technogenic aquifer near the rock-disposal dump base at the adjacent site of the open-pit mine. The results of this research form the basis for a substantiation of technical solutions for dewatering the north-eastern side of the PJSC INHZK openpit mine in the conditions of further development of mining operations, and for determining the hydrodynamic parameters of dewatering facilities.
\end{abstract}

\section{Introduction}

The open-pit mining of iron ore deposits in the conditions of technogenically disturbed hydrodynamic regime is often accompanied by the formation of large volumes of open-pit mine water influxes. This fact complicates mining works and leads to the development of

\footnotetext{
* Corresponding author: vasyl.tymoshchuk@gmail.com
} 
negative engineering-geological processes and phenomena in the sides of the open-pit mines $[1-4]$. The investigation of peculiarities of the open-pit mine water influx formation has been performed for the geological and hydrogeological conditions of the Inhulets iron ore deposit, which is developed by PJSC INHZK. The total volume of groundwater influx to the PJSC INHZK open-pit mine is $510-670 \mathrm{~m}^{3} / \mathrm{h}$, including water influx from the alluvial aquifer within the eastern side of the open-pit mine, about $90-120 \mathrm{~m}^{3} / \mathrm{h}$.

The development of landslide deformations and collapse phenomena in the area of occurrence of sandy-clay alluvial deposits and underlying sedimentary formations of the Neogene-Paleogene age should be distinguished among the number of consequences caused by flooding the eastern side of the open-pit mine, in particular of its north-eastern site $[5,6]$.

One of the factors influencing the nature of water seepage in the north-eastern side of the open-pit mine is the location within this area of the No. 3 rock-disposal dump. It creates an additional hydro-geomechanical loading onto the rock massif near the adjacent side of the iron ore open-pit mine.

The presence of significant open-pit mine water influx in the conditions of complex geological and hydrogeological structure of the iron ore deposit, as well as the existing spatial and temporal uncertainty of groundwater influx distribution within the north-eastern side of the open-pit mine complicates the development of effective technical solutions aimed at ensuring its hydra-geomechanical stability.

In this regard, the objective of the research is to study the patterns of formation of the open-pit mine water influx and its distribution within the eastern side of the PJSC INHZK open-pit mine and its north-eastern site for substantiation of effective technical solutions in their dewatering.

The object of research is geofiltration processes within the laminal rock massif in the conditions of the existing interconnection between the system components of the "northeastern side of the PJSC INHZK open-pit mine - No. 3 rock-disposal dump - floodplain of the Inhulets River' (Fig. 1).

In general, the mining and geological conditions of the north-eastern side of the PJSC INHZK open pit mine are determined by the complex hydrodynamic and geomechanical interaction of the natural and technical elements of the system 'iron ore open-pit mine No. 3 rock-disposal dump - alluvial deposits within the floodplain of the Inhulets River'. In addition, this interaction takes place in the conditions of geological environment disturbed in whole by mining works.

During the entire period of the Inhulets iron ore deposit mining, the groundwater influx into the open-pit mine was formed by drainage of the groundwater in the crystalline massif fractured zone, the terrigenous-carbonate deposits of the Paleogene-Neogene age and the quarternary alluvial aquifer of the Inhulets River floodplain.

Within the eastern side of the operating open-pit mine, the predominant share in the total volume of open-pit mine water influx belongs to the alluvial aquifer, which serves as the groundwater transit from the Inhulets River to the contour of their drainage in the interval of alluvial deposits developed by the side of the open-pit mine.

To protect the eastern side of the open-pit mine from the groundwater influx formed from the alluvial aquifer, the Inhulets River was directed and withdrawn to a distance of up to $400 \mathrm{~m}$, while along the eastern side of the open-pit mine the seepage cutoff wall has been constructed. It is a polyvinyl chloride film enclosed in a trench and filled with a bentonite clay solution with a designed permeability of $0.001 \mathrm{~m} /$ day.

The construction of the seepage cutoff wall has provided a sufficiently effective protection of the eastern side of the open-pit mine from water seeping from the Inhulets River, as evidenced by the difference in groundwater levels recorded in the observation wells on both sides of the seepage cutoff wall. However, the effectiveness of this wall over time has been significantly reduced due to numerous its discontinuity. 


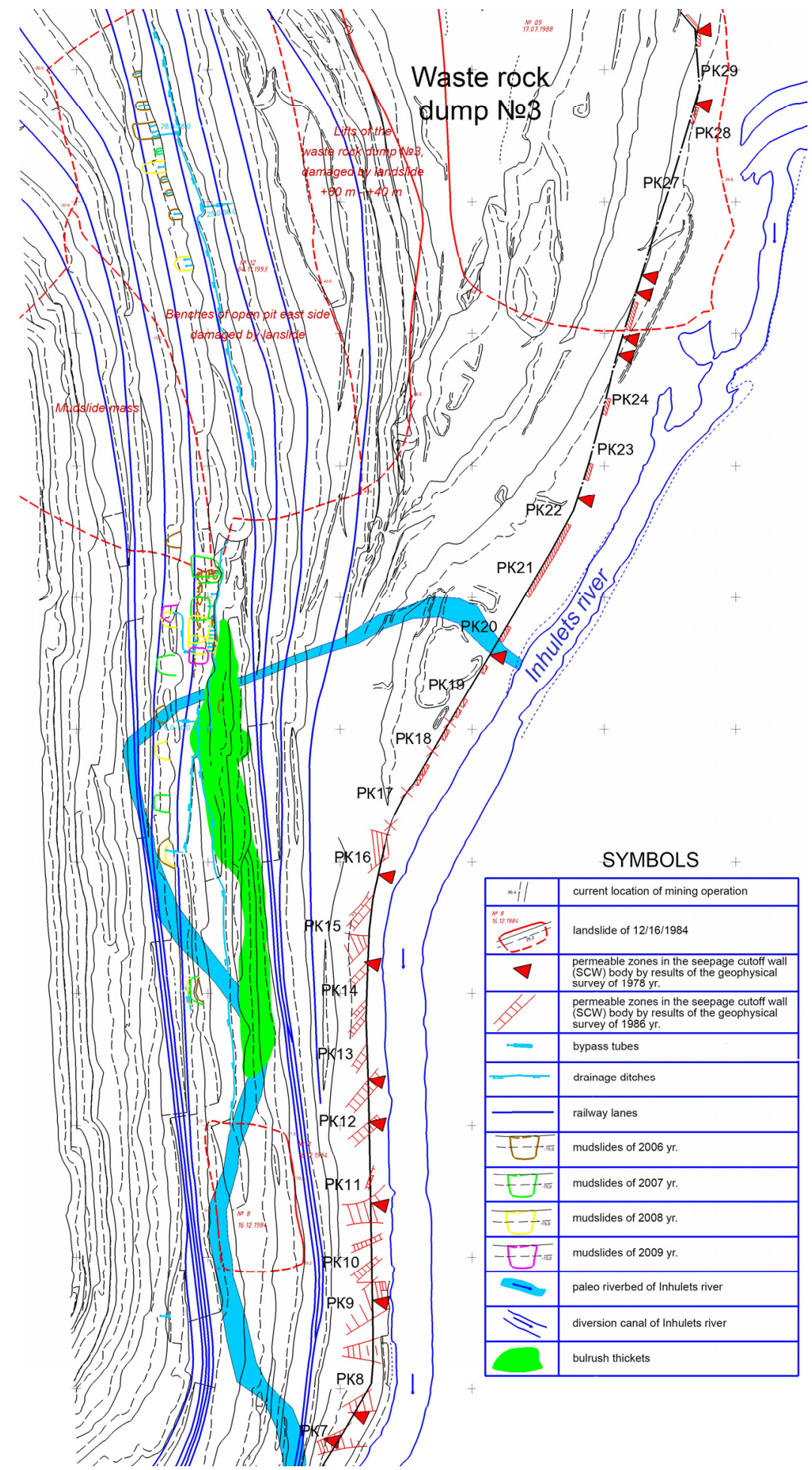

Fig. 1. The character of groundwater influx manifestation and related to it deformation processes within the eastern side of the open-pit mine (according to PJSC INHZK). 
The analysis of the engineering survey materials, regime observations data and the open-pit mine water influx dynamics observations have shown that to date the main sources of formation of the open-pit mine water influx within its north-eastern side are the seepage water from the Inhulets River, through which the dynamic resources formation of the alluvial aquifer, as well as infiltration recharge of the quarternary aquifer within the No. 3 rock-disposal dump location in the Inhulets River floodplain.

The decisive influence of a seepage from the Inhulets River on the open-pit mine water influx formation is evidenced by the influx dependence on the mutual position of the riverbed and the contour of the open-pit mine within its north-eastern side (see Fig. 1). The participation of seepage water in the alluvial aquifer recharge is also confirmed by the dynamical increase in flooding the eastern side of the open-pit mine and the chemical composition of groundwater, involved in the formation of open-pit mine water influx.

Analysis of the dependence of groundwater influx volume on climatic factors indicates the existence of a sufficiently stable relation between the open-pit mine water influx and the amount of atmospheric precipitation, as well as their distribution during a year in the conditions of the existing regime of the Inhulets River influence on mining operations. The determined dependence also allows to consider the formation of accumulative water within the No. 3 rock-disposal dump as one of the factors contributing to the flooding of the northeastern side of the open-pit mine at the site of its junction with the No. 3 rock-disposal dump located within the Inhulets River floodplain.

Indirect evidence of the accumulative water influence on the alluvial aquifer hydrodynamic regime at the site of the No. 3 rock-disposal dump is the landslide processes development within the north-eastern side of the open-pit mine and in the dump itself, which occurred during the whole time of the deposit mining. Thus, in the early 1980's, within the eastern side of the open-pit mine, there were several local landslides with a total volume of about 1 million cubic meters, the cause of which was the water-logging of weak clay rocks, which formed the benches of the open-pit mine sides with absolute elevations: $+24 \mathrm{~m},+12 \mathrm{~m}, \pm 0.0 \mathrm{~m},-15 \mathrm{~m}$.

The role of alluvial deposits in the floodplain of the Inhulets River is largely determined by its structure: the soil layer consists of consertal sandstone with pebble and gravel of quartz, and other solid crystalline rocks. They have a high hydraulic permeability, which ensures the transit of seepage water from the Inhulets River to the drainage boundary, that is to the eastern side of the PJSC INHZK open-pit mine.

A characteristic feature of the groundwater influx distribution within the eastern side of the open-pit mine and its northeastern site is their belonging to lower elevation area of Paleogene clay layer top up to absolute elevations less than $+20.0 \mathrm{~m}$, as a rule, from +10.0 to $+12.0 \mathrm{~m}$. Thus, according to PJSC INHZK data, intensive groundwater influx (up to $50 \mathrm{~m}^{3} / \mathrm{h}$ as of June 21,1989 ) within the north-eastern side of the open-pit mine and related to it large-scale landslide deformations at the junction with the No. 3 rock-disposal dump have coincided with the period of entering the open-pit mine side into the zone of Paleogene clay layer top (bottom of alluvial consertal sandstone) at elevations of -6.0 to $+7.0 \mathrm{~m}$.

\section{Modeling}

In conditions of complex hydrodynamic interaction of the geotechnical systems elements, the application of mathematical model technique has become widespread in the study of geofiltration processes [3, $7-9]$.

To study the conditions of the open-pit mine water influx formation and to determine the patterns of its distribution within the north-eastern side of the open-pit mine, we have created a geofiltration model of the studied area by means of the software complex MODFLOW 2009.1. When developing this model, the actual data were taken into account: 
the observations of groundwater influx within the eastern side of the open-pit mine; peculiarities of the alluvial strata occurrence at the junction of the open-pit mine with the No. 3 rock-disposal dump; patterns of permeability changes of water-bearing strata within the studied area; the character of hydraulic relation between the Inhulets River and waterbearing strata, as well as the predictive infiltration recharge elevation of the technogenic aquifer in the rock-disposal dump area.

The numerical model approximates the spatial groundwater flow with constant density in a porous medium. This model is described by the partial differential equation:

$$
\frac{\partial}{\partial x}\left(k_{x x} \frac{\partial h}{\partial x}\right)+\frac{\partial}{\partial y}\left(k_{y y} \frac{\partial h}{\partial y}\right)+\frac{\partial}{\partial z}\left(k_{z z} \frac{\partial h}{\partial z}\right)+W=S_{s} \frac{\partial h}{\partial t},
$$

where $k_{x x}, k_{y y}$ and $k_{z z}$ - hydraulic conductivities in directions of coordinate axes $X, Y$ and $Z ;(\mathrm{L} / \mathrm{T}) ; h$ - potentiometric head $(\mathrm{L}) ; W$ - volumetric flux per unit, representing sources and sinks of water $\left(\mathrm{T}^{-1}\right)$ : for inflow $W>0$, for outflow $-W<0 ; S_{S}-$ specific storage of porous environment $\left(\mathrm{L}^{-1}\right) ; t$ - time $(\mathrm{T})$.

An equation (1), together with the boundary and initial conditions, describes a threedimensional transient groundwater flow in a heterogeneous and anisotropic medium, provided that the main directions of the hydraulic conductivities coincide with the directions of the coordinate axes [10 - 12].

The calculation mapping of the studied area has been done in accordance with the peculiarities of the geological structure, the character of occurrence of water-bearing rocks and waterproof rocks, as well as their hydraulic properties, the existence of a hydraulic relation between the surface water and groundwater, specifics of aquifer recharge and discharge along their area and along their contours $[8,9]$.

The dimensions of the simulated area have been determined within the territory of $4600 \times 2400 \mathrm{~m}$, respectively, in the meridional and latitudinal directions with a total area of a model of $11.0 \mathrm{~km}^{2}$. The simulated area is represented by a grid of blocks with dimensions of $25 \times 25 \mathrm{~m}$ in order to approximate thoroughly the current configuration of the Inhulets River, the contour of the north-eastern side of the open-pit mine and the seepage cutoff wall, as well as of the hypsometry of rock layers and groundwater levels in the alluvial aquifer.

The model structure has an eight-layer thickness (Fig. 2), according to the rocks stored into the No.3 rock-disposal dump, the geo-lithological structure of water-bearing deposits in alluvial aquifer, that include the Paleogene clays (later Eocene) and coal and clay strata of the middle Eocene, the lower layer of which according to the geological structure of the considered area is a fractured zone of ore-bearing crystalline massif.

As the hydrodynamic boundaries on the external contours of the model, the remote boundaries with constant recharge have been assigned, corresponding to the boundaries of the third kind (throughflow) $Q=f(H)$, according to the general hydrodynamic scheme of the studied area.

The values of hydraulic heads on the model contours are determined from the data of exploratory drilling in accordance with groundwater elevations within the studied sites of the simulated area, and this relates to a decisive influence of geomorphological structure on its hydrodynamic regime. The water conductivity values on the external contours of the calculated layers have been determined from the averaged values of the lithological varieties permeability within separate sites of the model area and range from $3.6 \cdot 10^{-5}$ to $102.46 \mathrm{~m}^{2} /$ day.

On the contour sites of the simulated area, where the inflow/outflow is absent in accordance with the groundwater flow direction, the contours with the boundary condition of the second kind $(Q=0)$ have been assigned. 


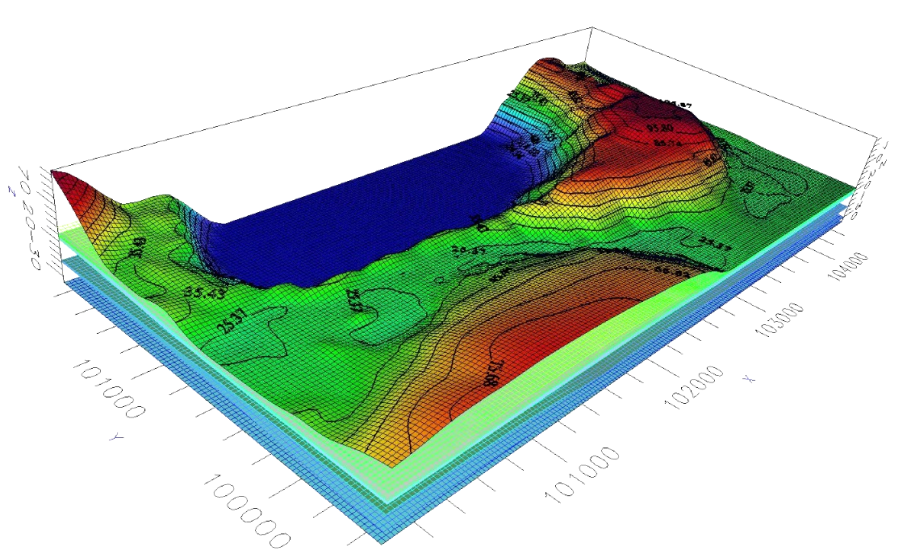

Fig. 2. Structure of the simulated area within the eastern side of the PJSC INHZK open-pit mine.

The inner hydrodynamic boundary of the model is the Inhulets River. Within the studied area the Inhulets River has its absolute elevations of $22.05-22.50 \mathrm{~m}$, its width varies from 50.0 to $75.0 \mathrm{~m}$, averaging $60.0 \mathrm{~m}$, the depth varies from 1.6 to $2.0 \mathrm{~m}$, reaching $2.5 \mathrm{~m}$ at separate sites.

In terms of hydrodynamics, the Inhulets River in the numerical model is represented by the boundary conditions of the third kind, which consider the interconnection of surface water and groundwater determined by the riverbed conductivity. The parameters of water conductivity of riverbed deposits within the calculated blocks of the model have been assigned in accordance with the alluvial deposits permeability with values from 0.000625 to $4312.5 \mathrm{~m}^{2} /$ day.

The drainage contour of alluvial deposits within the north-eastern side of the open-pit mine is determined by the position of the bottom hypsometry of consertal sandstone layer underlaid by the Paleogene clay, and opened by a side of the open-pit mine.

The seepage cutoff wall (SCW) operation was simulated by setting a low-permeable 'wall' at a distance of $25-50 \mathrm{~m}$ from the western bank of the Inhulets River, deepened along its entire length to the siltstone clay layer top (calculated layer 6). In accordance with the design parameters of the seepage cutoff wall, its width was assigned equal to $0.7 \mathrm{~m}$ with its material permeability of $0.05 \mathrm{~m} /$ day.

The calculated values of hydraulic conductivity, accepted in accordance with the structure of the numerical model and specified by the results of inverse problems solution, are given in Table 1 .

Table 1. Calculated parameters of permeability and porosity of a numerical model

\begin{tabular}{|l|c|c|c|}
\hline \multirow{2}{*}{ Calculated layer } & \multicolumn{3}{|c|}{ Permeability and porosity parameters } \\
\cline { 2 - 4 } & $\begin{array}{c}\text { permeability coefficient, } \\
K\left(K_{X}=K_{Y}=K_{Z}\right), \\
\mathrm{m} / \text { day }\end{array}$ & $\begin{array}{c}\text { specific yield } \\
\mu, \% .\end{array}$ & $\begin{array}{c}\text { specific storage } \\
\mu^{*}, \mathrm{~m}^{-1}\end{array}$ \\
\hline Layer 1 - rock-disposal dump & $0.5-0.7$ & 10.0 & 0.0001 \\
\hline Layer 2 - loam and sandy loam & $0.001-0.7$ & 10.0 & 0.0001 \\
\hline Layer 3 - fine sand & $0.001-0.84$ & 15.0 & 0.00001 \\
\hline Layer 4 - sandy clay & 0.001 & 2.0 & 0.00001 \\
\hline Layer 5 - consertal sandstone & $6.9-13.0$ & 20.0 & 0.00001 \\
\hline Layer 6 - siltstone clay & 0.00001 & 1.0 & 0.00001 \\
\hline Layer 7 - coal clay & 0.0005 & 1.0 & 0.00001 \\
\hline Layer 8 - weathered shale & 0.00005 & 1.0 & 0.00001 \\
\hline
\end{tabular}


The infiltration value within the studied area ranges from 13 to $42 \mathrm{~mm} /$ year [13]. At the location of the No. 3 rock-disposal dump, composed of oxidized and semi-oxidized jaspilite and overburden rocks, the infiltration recharge value was assumed equal to $50 \mathrm{~mm} / \mathrm{year}$ at the stage of the inverse problem solution - taking into account the extra recharge in accordance with the recommendations for industrial areas of the mining and metallurgical complex, with the possibility of its further adjustment.

According to the calibration data, the deviation of the calculated groundwater elevations in the alluvial aquifer comparatively to the measured ones does not exceed $1.364 \mathrm{~m}$ (Fig. 3). The standard error of the estimate defined by the results of performed calculations is $0.126 \mathrm{~m}$. The significance of statistical estimates is characterized by a value of $R^{2}=0.737 \mathrm{~m}$ and its standardized value of $8.126 \%$.

In terms of considered conditions, the above estimates indicate a satisfactory convergence of the modeling results, taking into account the existing heterogeneity of the alluvial aquifer permeability and the inconstant character of the spatial occurrence of waterbearing layers and waterproof layers, separating them.

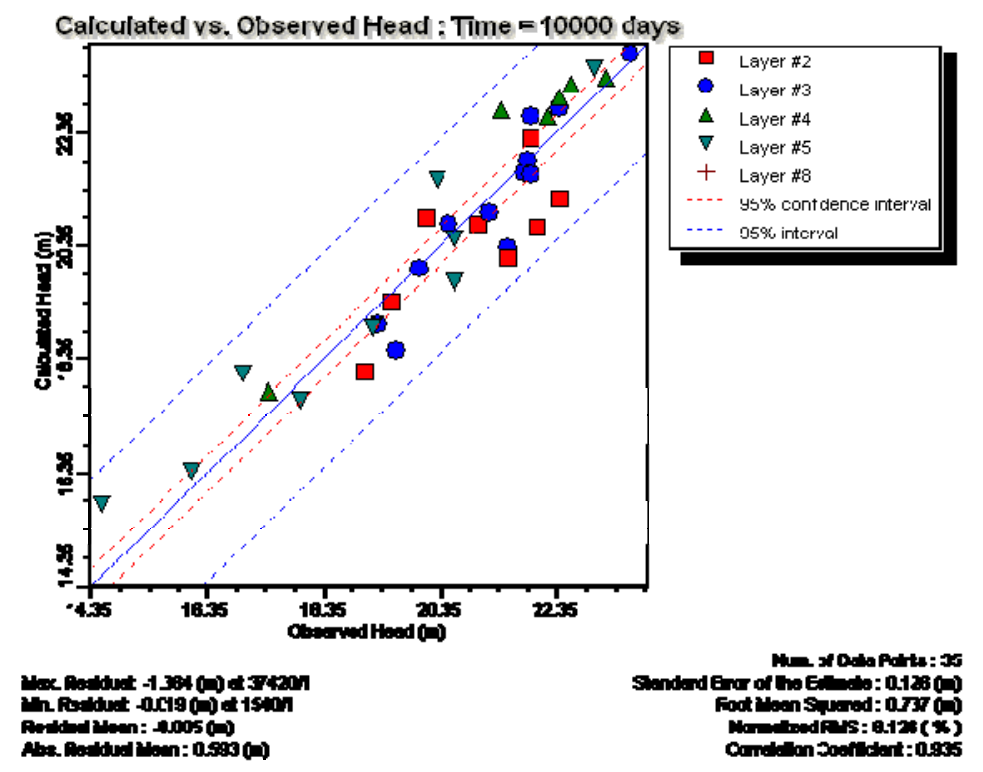

Fig. 3. Calibration plot of measured hydraulic heads plotted against MODFLOW-simulated heads as of April-May 2015 - inverse problem solution, transient flow regime.

\section{Results}

MODFLOW-simulated groundwater heads at the baseline of the rock-disposal dump and the alluvial aquifer within the studied territory, which were obtained from the inverse problems solution in accordance to the accepted hydrodynamic scheme for the period of engineering surveys are presented in Fig. $4-6$.

According to modeling results, the formation of the hydrodynamic regime of the alluvial aquifer in the studied area occurs due to infiltration of atmospheric precipitation, lateral inflow from the watershed sites (eastern boundary of the simulated area), and inflow of seepage water from the Inhulets River; and discharge occurs by leaving the permeable rocks on their drainage contour within the eastern side of the open-pit mine.

At the same time, the seepage from the Inhulets River has the significant value for the 
alluvial aquifer recharge, which is located directly in the drainage zone of the open-pit mine.

MODFLOW-simulated groundwater influx on the discharge contour of the alluvial aquifer is well correlated with the measured values of the groundwater influx within the eastern side of the iron ore open-pit mine.

According to PJSC INHZK data, the total groundwater influx towards the eastern side of the open-pit mine as of 2015 reached $90-120 \mathrm{~m}^{3} / \mathrm{h}$ or $2160-2880 \mathrm{~m}^{3} /$ day. Based on the data of MODFLOW-simulated inverse problem solution, the total value of drainage water intake for this contour is $2374.9 \mathrm{~m}^{3} /$ day or $98.9 \mathrm{~m}^{3} / \mathrm{h}$, which indicates a satisfactory convergence of the calculated groundwater influx values with the measured data within the eastern side of the open-pit mine. Taking into account the losses due to the bottom of alluvial aquifer at the southern site of the side of the open-pit mine at the level of $551.6 \mathrm{~m}^{3} / \mathrm{day}\left(22.9 \mathrm{~m}^{3} / \mathrm{h}\right)$, the total estimated influx towards the eastern side is about $121.8 \mathrm{~m}^{3} / \mathrm{h}$.

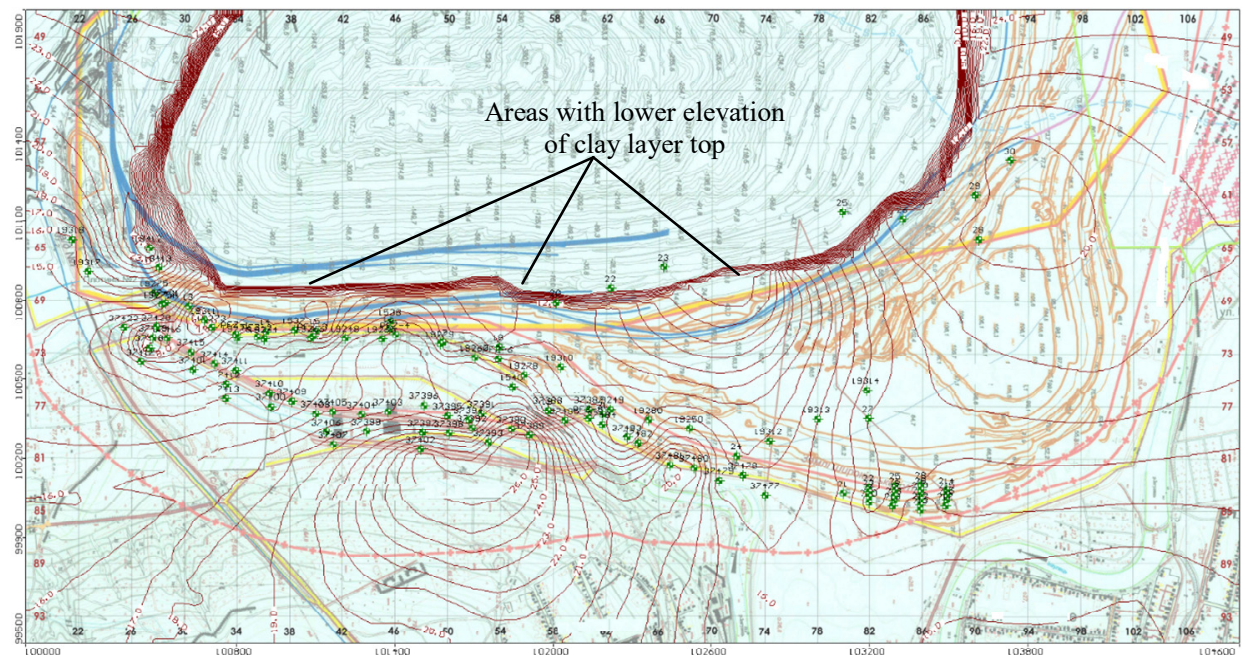

Fig. 4. Elevation of Paleogene clay layer top within the eastern side of the PJSC INHZK open-pit mine, $\mathrm{m}$.

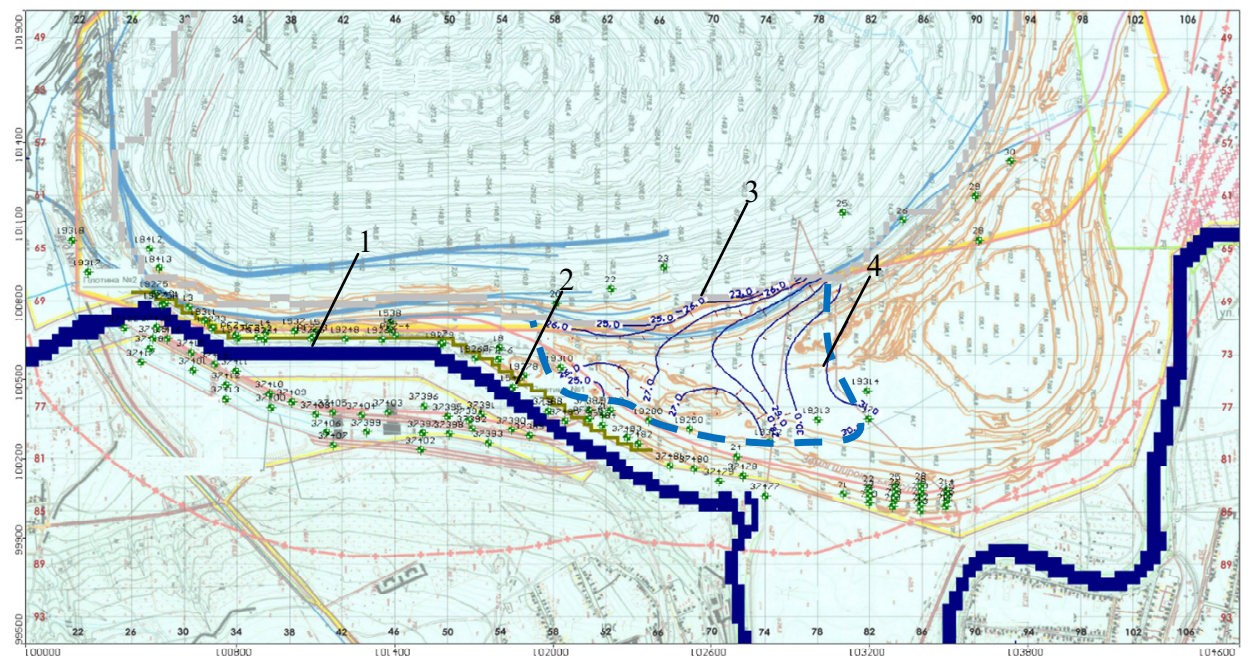

Fig. 5. MODFLOW-simulated groundwater heads at the baseline of №3 rock-disposal dump as of April-May 2015 - inverse problem solution, transient flow regime, m: 1 -current position of the Inhulets River; 2 - seepage cutoff wall; 3 - groundwater flow direction; 4 - technogenic aquifer. 


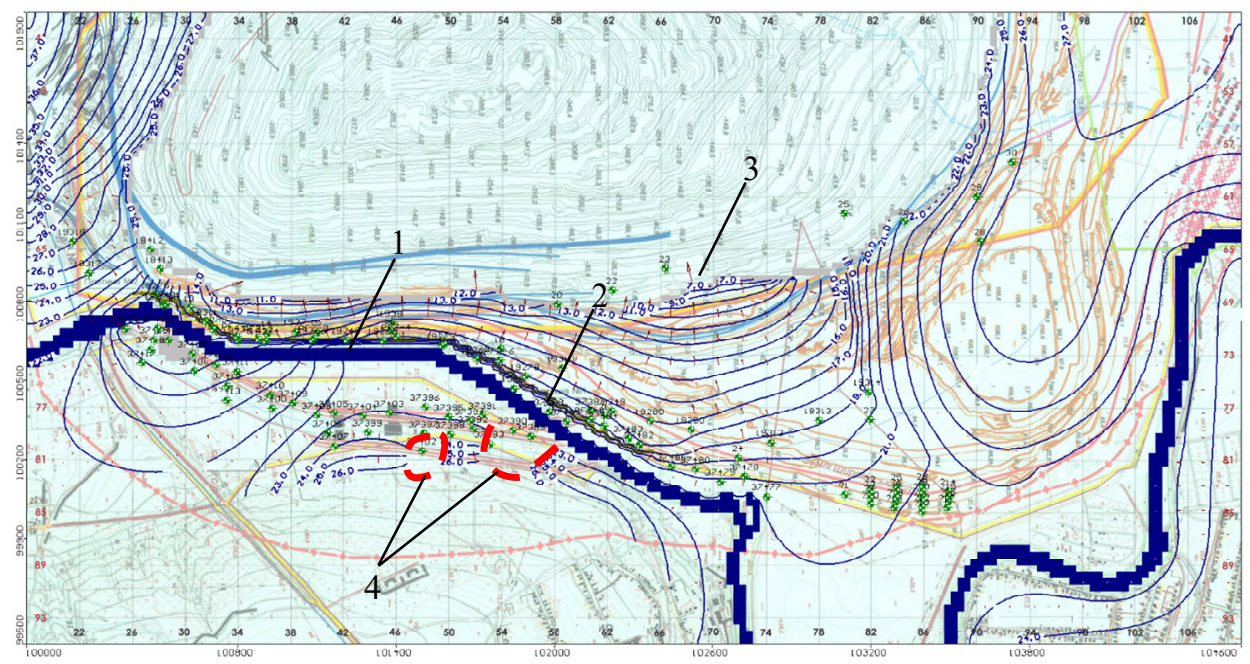

Fig. 6. MODFLOW-simulated groundwater heads of alluvial aquifer as of April-May 2015 - inverse problem solution, transient flow regime, m: 1 - current position of the Inhulets River; 2 - seepage cutoff wall; 3 - groundwater flow direction; 4 - "dry" zones.

The distribution of calculated groundwater influx values along the open-pit mine contour is characterized by relative concentration of groundwater influx within the sites $30-42\left(831.29 \mathrm{~m}^{3} /\right.$ day $), 50-58\left(436.87 \mathrm{~m}^{3} /\right.$ day $)$ and $62-74\left(587.28 \mathrm{~m}^{3} /\right.$ day $)$ of $\operatorname{mine}$ surveying axes (s.a.). The position of these sites coincides with the location of the relatively reduced elevation of the Paleogene clay layer top (Fig. 7). The values of the MODFLOWsimulated groundwater influx within the allocated areas reach the values of $13.2 \mathrm{~m}^{3} / \mathrm{h}(\mathrm{s} . \mathrm{a}$. of $38-42$ ) and $9.5-10.4 \mathrm{~m}^{3} / \mathrm{h}$ (s.a. of $50-54,66-70$ ).

Significant groundwater influx in the area of s.a. $30-42$ is related to the proximity of the southern site of the open-pit mine eastern side to the existing bed of the Inhulets river. According to modeling results, the total groundwater influx value at this site is $34.6 \mathrm{~m}^{3} / \mathrm{h}$, which is consistent with the groundwater influx in situ observations - the visually estimated groundwater influx value within the mentioned axes is in the range of $33.0-56.0 \mathrm{~m}^{3} / \mathrm{h}$.

As defined by the modeling results, the presence of a local zone for descending discharge of the alluvial aquifer into the fractured zone of the underlying parent rock, is characteristic for this site. This fact is evidenced by the surface-level deformations of the alluvial aquifer, which are confined to the areas with lower elevations of the clay layer top.

Relatively low calculated values of groundwater influx within 58-90 mine surveying axes $-785.16 \mathrm{~m}^{3} /$ day $\left(32.71 \mathrm{~m}^{3} / \mathrm{h}\right)$ are explained by the relative removal of the Inhulets River from the northern site of the open-pit mine eastern side. The current situation is confirmed by the actual observation data: at the end of April 2015, the groundwater influx into the open-pit mine along the mine surveying axes $50-70$ did not exceed $21.30 \mathrm{~m}^{3} / \mathrm{h}$. The water influx, determined for this period, has been recorded after elimination of water manifestations at the horizon +12.0 (measurements on 04/02/2015) and a decrease in groundwater influx at the horizon -30.0 (surveying axes $65-70$ ) from 68.18 to $15.36 \mathrm{~m}^{3} / \mathrm{h}$ according to the measurements, respectively on $25 / 03 / 2015$ and $04 / 02 / 2015$.

We have carried out the comparative assessment of the groundwater influx to the northeastern site of the open-pit mine during different periods of iron ore deposit mining and defined the direct correlation of their values on the hypsometric of the layer bottom of heterogeneous gravel sands within the contour of their development by the eastern side of the open-pit mine. 


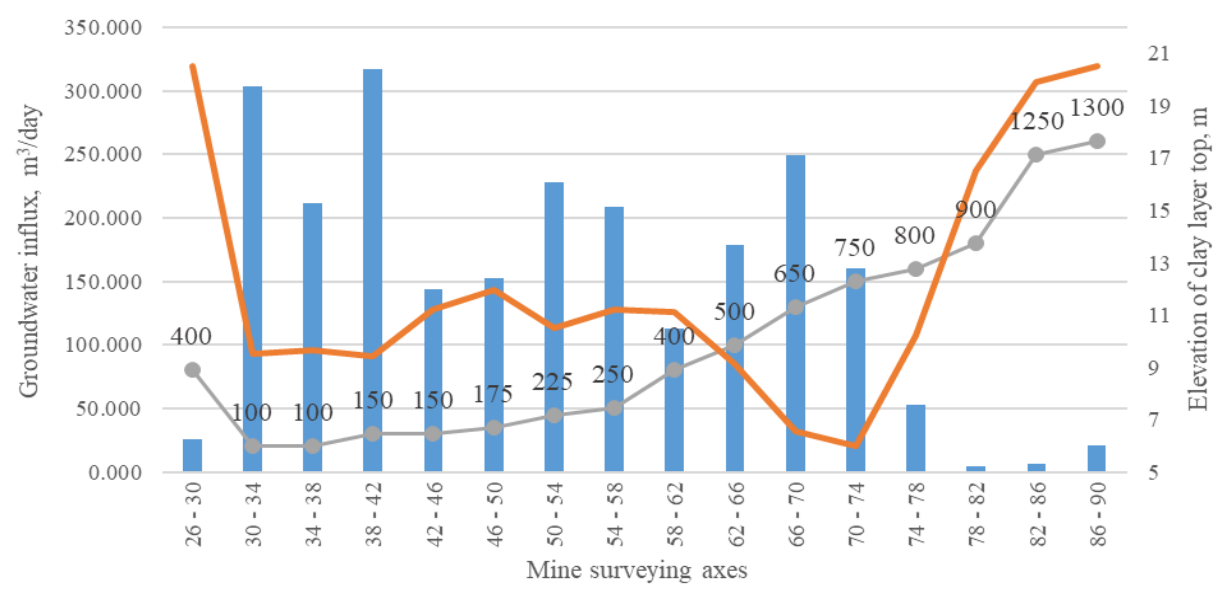

Groundwater influx, cubic meter/day - Distance to the river, $\mathrm{m} \longrightarrow$ Elevation of clay layer top, $\mathrm{m}$

Fig. 7. Comparative diagram of the layer top elevation of Paleogene clay, the values of groundwater influx into the open-pit mine and the distance from the open-pit mine contour to the Inhulets River along the eastern side of the open-pit mine.

The above is confirmed by the results of hydrodynamic modeling, according to which the concentration of groundwater influx in ranges of 50-58 and $62-74$ surveying axes coincides with the lowered absolute elevations up to $10.4-12.0 \mathrm{~m}$ and $5.5-10.4 \mathrm{~m}$ of the layer bottom of gravel sand lying on the Paleogene clay within the north-eastern site of the open-pit mine side.

The groundwater influx distribution within the open-pit eastern side indicates that influx values depend on the bottom hypsometry of the heterogeneous gravel sands, lying on the eroded surface of Paleogene clay, the presence and distribution of waterproof alluvial clay layer in the roof of the gravel sand, the hydraulic permeability of them at particular sites of the Inhulets River floodplain and the infiltration value of the alluvial aquifer recharge both within the floodplain and at the site of the №3 rock-disposal dump location.

According to the modeling data, it has been found that the presence of strata with reduced hydraulic permeability at the base of the No.3 rock-disposal dump in conditions of increased infiltration recharge leads to the water-saturated zone formation in the lower range of the rock dump with the general direction of its surface slope towards the southwest and south-east and with the absolute elevations of $24.1-31.4 \mathrm{~m}$.

With the value of infiltration recharge within the rock dump of $50 \mathrm{~mm} / \mathrm{year}$, the groundwater influx values from the technogenic horizon on the contour of the open-pit mine in the range of s.a. $54-82$ reach $28.27 \mathrm{~m}^{3} /$ day $\left(1.2 \mathrm{~m}^{3} /\right.$ year $)$.

\section{Conclusions}

When carrying out the research, a spatial geofiltration model has been developed of the eastern side of the PJSC INHZK open-pit mine and its north-eastern site, which, in accordance with the general hydrodynamic scheme, represents the main patterns in the recharge and discharge of the alluvial aquifer formed within the studied area. The main patterns that we have taken into account are the constant recharge of the alluvial aquifer by the seepage water of the Inhulets River and the additional infiltration recharge from the No. 3 rock-disposal dump located within the floodplain, in the zone where the alluvial aquifer is drained by the eastern side of the open-pit mine. 
The values of groundwater influx and the particularity of its distribution, determined by the results of modeling, are consistent with the measured water influx values and its distribution both within the entire eastern side of the open-pit mine and within its northeastern site. With a total volume of groundwater influx towards the eastern side of the open-pit mine at a level of $2374.9 \mathrm{~m}^{3} /$ day or $98.9 \mathrm{~m}^{3} / \mathrm{h}$, its maximum is $316.8 \mathrm{~m}^{3} /$ day $\left(13.2 \mathrm{~m}^{3} /\right.$ year $)$ in the mine surveying axes interval $38-42$ and gradually decreases in the northern direction to $159.8-249.1 \mathrm{~m}^{3} /$ day $\left(6.7-10.4 \mathrm{~m}^{3} / \mathrm{h}\right)$. This is determined by the relatively remote location of the side of the open-pit mine, being a drainage of the alluvial aquifer, from the Inhulets River.

A characteristic feature in the distribution of groundwater influx values within the eastern side of the open-pit mine is their dependence on the manner of heterogeneous gravel sands occurrence on the eroded surface of Paleogene clay. The natural growth of the calculated groundwater influx within the eastern side of the open-pit mine corresponds to areas of lowered (up to $5.5-12.0 \mathrm{~m}$ ) elevations of layer bottom of the gravel sand aquifer. With the existing stage of mining, there are two such sites in the eastern area of the open-pit mine - within the s.a. $50-58$ and $62-70$, where the values of MODFLOW-simulated groundwater influx reach $249.09 \mathrm{~m}^{3} /$ day $\left(10.38 \mathrm{~m}^{3} / \mathrm{h}\right)$.

According to the modeling results, it has been established that the hydrodynamic impact of the No.3 rock-disposal dump within the north-eastern side of the open-pit mine is determined by both the infiltration recharge value at the site of the rock-disposal dump location and the possible occurrence of a layer with low-permeable pressed rocks in its base, which leads to the water-saturated zone formation in the lower range of the rock dump with the general direction of its surface slope towards the south-west and south-east and with the absolute elevations of $24.1-31.4 \mathrm{~m}$.

The research was carried out with the cooperation and technical support of the specialists from the Private Joint-Stock Company "Inhuletskyi hirnycho-zbahachuvalnyi kombinat" Head Geological Department.

\section{References}

1. Ahkozov, Yu.L., Chupriy, S.V., \& Mechnikov, Yu.P. (2006). Vliyanie tektonicheskogo faktora na inzhenerno-geologicheskie svoystva porod osadochnogo chekhla Inguletskogo mestorozhdeniya (Krivorozhskiy basseyn). Heoloho-mineralohichnyi visnyk, 2(16), 100-103.

2. Bahrii, I., Blinov, P., \& Bielokopytova, N. (2002). Heoekolohichni problemy Kryvorizkoho baseinu v umovakh restrukturyzatsii hirnychodobuvnoi haluzi. Kyiv: Feniks.

3. Rudakov, D., Timoschuk, V., Perkova, T., \& Sherstyuk, E. (2011). Identifikatsiya trekhmernoy geofiltratsionnoy modeli tekhnogenno nagruzhennoy territorii tsentral'noy chasti Krivorozhskogo basseyna. Naukovyi Visnyk Natsionalnoho Hirnychoho Universytetu, (5), 21-25.

4. Timoshuk, V., Demchenko, J., \& Sherstuk, Y. (2010). The role of natural and technogenic components in failure of geomechanical stability of the territories which are in the influence zone of mining objects. New Techniques and Technologies in Mining, 189-192. https://doi.org/10.1201/b11329-31

5. Stetsenko, A. (2018). Lithology and geochemistry of sedimentary rocks in Pavlivsk field in the western part of the Kryviy Rih structure. Visnyk of V.N Karazin Kharkiv national university-series geology geography ecology, (48), 92-103. https://doi.org/10.26565/2410-7360-2018-48-07

6. Tadyeyev, O. (2017). To the problem of elimination of invariance loss effects in the evaluation of deformation fields of the earth using GNSS-data. Geodynamics, 1(23), 34-45. https://doi.org/10.23939/jgd2017.02.034

7. Sadovenko, I., Zahrytsenko, A., Podvihina, O., \& Dereviahina, N. (2017). Water balance control within rock mass using the capacity of water-bearing formations. Naukovyi Visnyk Natsionalnoho Hirnychoho Universytetu, 4(160), 19-27. 
8. Timoshchuk, V.I., \& Sherstyuk, Ye.A. (2012). Geofiltration regularities in the areas loaded by gravitation in tailings and waste rock dumps. Naukovyi Visnyk Natsionalnoho Hirnychoho Universytetu, (4), 30-36.

9. Tymoshchuk, V., Tishkov, V., \& Sherstyuk, E.A. (2013). Hydrodynamic substantiation of water control measures at the site of sludge collector in Yasinovaya valley, Dnipropetrovsk oblast. Naukovyi Visnyk Natsionalnoho Hirnychoho Universytetu, (3), 5-10.

10. Kinzelbach W. (1986). Groundwater modeling. Amsterdam: Elsevier.

11. McDonald, M.G., \& Harbaugh, A.W. (1984). A modular three-dimensional finite-difference ground-water flow model. U.S. Geological Survey Open-File Report 83-875.

12. Schlumberger. (2009). Visual MODFLOW 2009.1 User's Manual. 1st ed. Waterloo, Ontario, Canada: Schlumberger Water Services.

13. Grinevskiy, S., \& Novoselova, M. (2010). Zakonomernosti formirovaniya infil'tratsionnogo pitaniya podzemnykh vod. Vodnye resursy, 37(6), 1-12. 